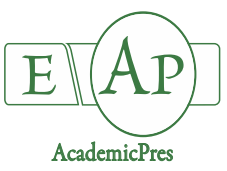

Butcaru AC et al. (2020)

Notulae Botanicae Horti Agrobotanici Cluj-Napoca 48(2):692-704

DOI: $10.15835 /$ nbha 48211792

Research Article

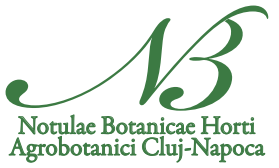

\title{
Influence of organic technology on vegetative growth and production of three climbing edible roses (Rosa sp.)
}

\author{
Ana Cornelia BUTCARU, Florin STĂNICĂ, Sorina Aurelia PETRA* \\ University of Agronomic Sciences and Veterinary Medicine of Bucharest, 59 Mărăști Bv., 011464, Bucharest, Romania; \\ anabutcaru@gmail.com; flstanica@yahoo.co.uk; sorina.petra@gmail.com (*correspondingauthor)
}

\begin{abstract}
In the present study, three climbing edible roses ('Crown Princess Margareta', 'Falstaff and 'Brother Cadfael') were evaluated for total vegetative growth and flowers production besides correlations with soil microbiological and agrochemical parameters. The applied organic technology included a soil preparatory stage with three ameliorative plants (Sinapis alba L., Phacelia tanacetifolia L. and Tagetes patula L.) and two organic mulch variants (wood chips and wool) after plantation. In variant Sinapis and Tagetes, all three varieties of roses showed the highest values for parameters: total vegetative growth, number of shoots, average shoots length and flowers number. Significant positive correlations between biometric parameters and soil bacteria, phosphorus, mineral nitrogen, potassium $(0-20 \mathrm{~cm}$ horizon) and humus $(20-40 \mathrm{~cm}$ horizon) content were observed. Significant positive correlations between the number of flowers and the soil respiration coefficient, soil content in phosphorus, potassium, humus, total soluble salts and mineral nitrogen were noticed. Negative correlations with soil $\mathrm{pH}$ have been observed. Taking into account the data obtained in the two flowering stages in 2017, the average yield per hectare cultivated with 'Crown Princess Margareta' was $9.44 \mathrm{t}$ petals/ha. For the 'Falstaff and 'Brother Cadafael' cultivars, the yields were 7.54 and $5.62 \mathrm{t}$ petals per hectare respectively.
\end{abstract}

Keywords: Phacelia tanacetifolia L.; Sinapis alba L.; soil agrochemical parameters; soil microbioly; Tagetes patula L.; wood chips mulch; wool mulch

\section{Introduction}

Edible roses have been classified by many authors (Bojor and Răducanu, 2007; Milică et al., 2010; Stănică and Braniște, 2011; Sumedrea et al., 2014) within species of the genus Rosa such as Rosa rugosa Thunb., Rosa centifolia L., Rosa damascena Mill., of whose petals can be used for the jam production. But many breeders (David Austin in the United Kingdom, Rosen Tantau and Kordes in Germany, Meilland in France, etc.) offer a large series of rose cultivars that are not of the above species and have the word 'edible' (which can be used in food industry for jam, sweetness, syrup, etc.). Vinokur et al. (2006) and Friedman et al. (2010) defined the edible rose as the rose whose petals are not bitter or astringent and have a texture suitable for consumption, extending the notion of edible roses to thousands of cultivars. The rose has been also used since ancient times as a medicinal plant (Lambraki, 2001; Hessayon, 2005; Milică et al., 2010; Lia et al., 2014; Dong et al., 2017; 
Fernandes et al., 2017). Bojor and Răducanu (2010) provided details on the pharmacological properties, mentioning the rich content in tannin of petals, having anticancer, slightly laxative, aphrodisiac, decongestant, disinfectant, antiseptic, haemostatic activity. Rose syrup has been recommended in the treatment of mouth, migraine and neuralgia. Milică et al. (2010) mentioned the role of rose jam in the treatment of lung disorders and oral cavity. The use of rose both in medical and food industry was mentioned by Lambraki (2001), VasilcaMozăceni (2002) and Hessayon (2005) with details on the different products that can be obtained. The edible rose had great nutritional properties, being recommended by its content in carotenoids, anthocyanins, flavonic derivatives, tannins, vitamins, etheric oils etc. (Milică et al., 2010). The aim of this research, taking into account the criterion mentioned by Vinokur et al. (2006) and Friedman et al. (2010) and the possible use in medicinal or food industry, was to study the behavior of three climbing edible roses 'Crown Princess Margareta', 'Falstaff and 'Brother Cadfael' varieties under an organic technology.

\section{Materials and Methods}

\section{Description of the study site}

The research has been carried out in the Experimental Field of Faculty of Horticulture within USAMV Bucharest and in the Research Centre for Studies of Food and Agricultural Products Quality. In 2015, an organic rose culture of a total area of $1,350 \mathrm{~m}^{2}$ with three climbing edible cultivars: 'Falstaff, 'Brother Cadfael' and 'Crown Princess Margareta' (Austin, 2012) was established and an organic technology was applied, including increasing soil biologic activity using three ameliorative species: Sinapis alba L., Phacelia tanacetifolia L. and Tagetes patula L. before and after planting. On the row, the soil was mulched with wool and wood chips and for irrigation, a drip system was used (Butcaru et al., 2017; Matei $e t$ al., 2017). The inter-row was kept grassy through repeated mowing. Different bio-stimulators, fertilizers and plant protection specific strategy were used (Butcaru et al., 2018).

\section{Biological material}

Three climbing edible roses from David Austin collection ('Crown Princess Margareta', 'Falstaff and 'Brother Cadfael' grafted on Rosa laxa Retz) were analyzed. 'Crown Princess Margareta', created in 1999, is a climbing rose, apricot colour flowers, strong and fruity fragrance. With a vigorous growth, the height can be 250-300 cm, with repeated flowering (Figure 1A). 'Falstaff, created in 1999, is a climbing rose, dark crimson colouring, with a height of $250-300 \mathrm{~cm}$. It has repeated flowering, large and full petalled flowers (Figure 1B). 'Brother Cadfael', created in 1986, has large, globular, pink flowers, old rose strong fragrance. With vigorous vegetative growth, it can reach 250-300 cm high (Figure 1C) (Beales et al., 1998; McKinley, 2008; Wagner, 2010; Austin, 2012).

\section{Experimental design}

All the three ameliorative species used (Sinapis alba L., Phacelia tanacetifolia L. and Tagetes patula L.) were sown combining the three species in seven variants: V1 Sinapis, V2 Sinapis + Phacelia, V3 Phacelia, V4 Sinapis + Tagetes, V5 Sinapis + Tagetes + Phacelia, V6 Tagetes + Phacelia, V7 Tagetes and a control parcel V8, was kept as black field, without sowing. They were trimmed and incorporated into the soil after the flowering period. Starting with 2016, on the rose rows, the soil was mulched with wool and wood chips for each initial variant (Vn): Vn.1 wood chips and Vn.2 wool, while the control Vn.3, was represented by unmulched soil. Both mulched rows had the same $1 \mathrm{~m}$ width with the specific material (Figure 2). 


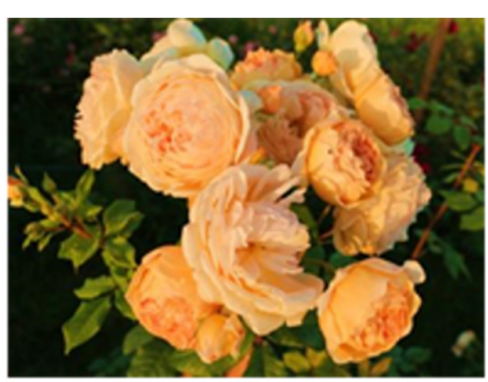

A

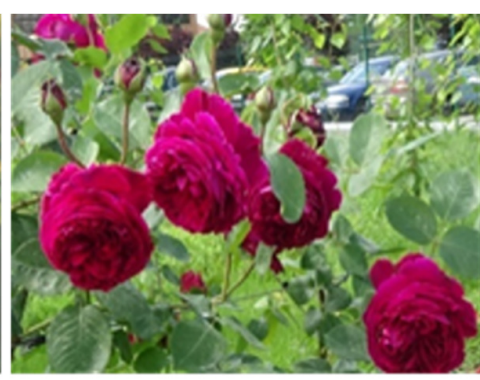

B

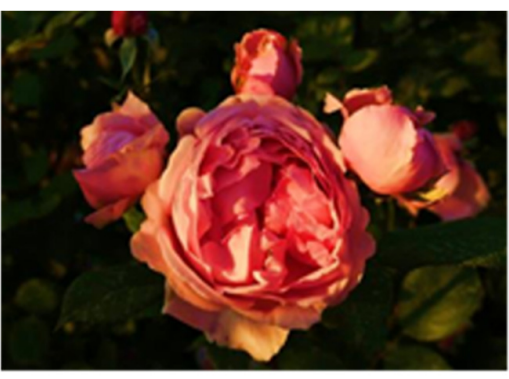

C

Figure 1. Three climbing roses 'Crown Princess Margareta' (A), 'Falstaff (B) and 'Brother Cadfael' (C)

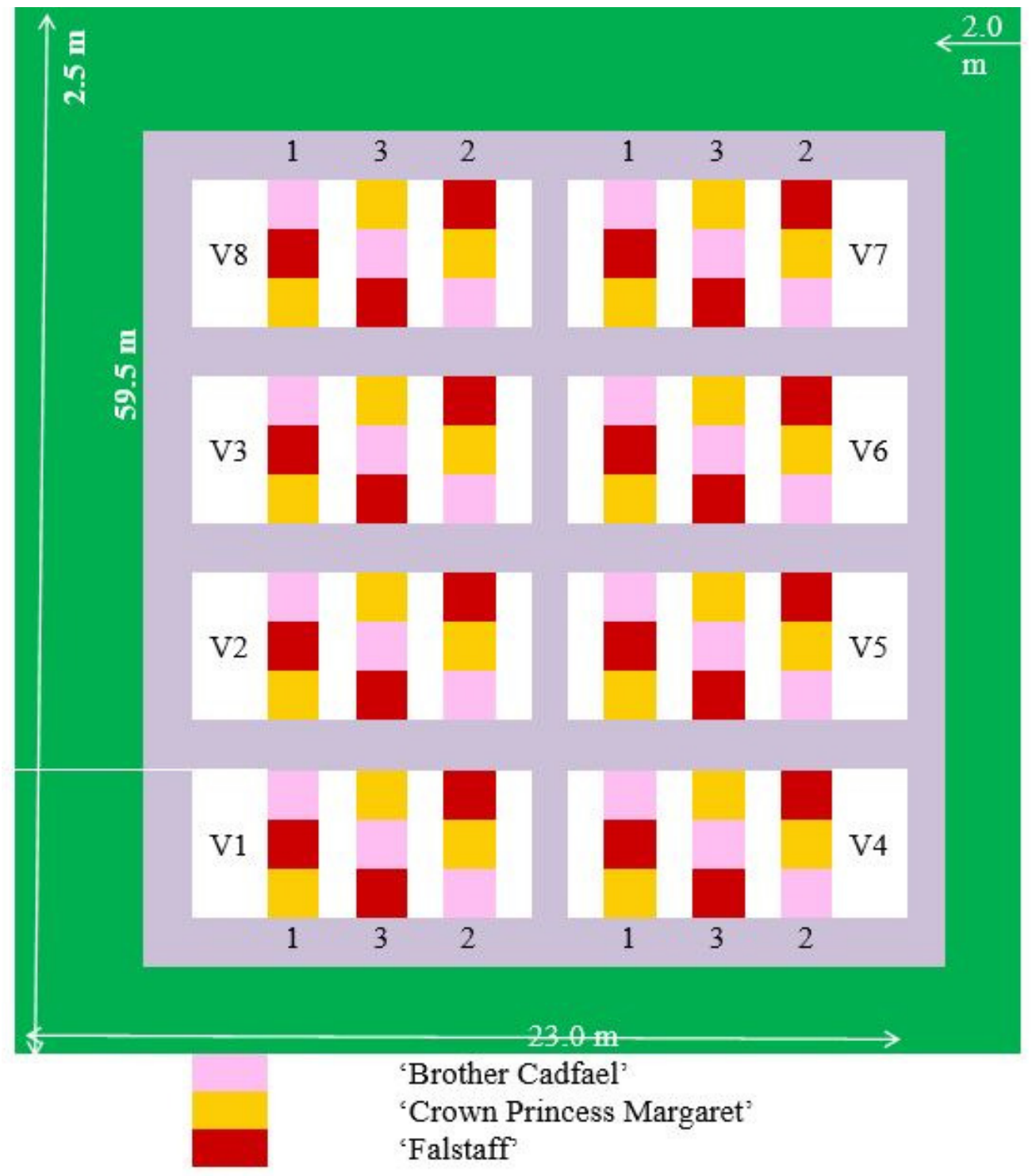

Figure 2. Experimental design (ameliorative plants, mulch and rose cultivars) 
For 2017 year, after counting the flowers number in the first and second flowering stage, estimated production was made for fresh and dried petals. To estimate the flower and petals weight, 10 flowers per each cultivar were collected. They were also weight after their dehydration with a dehydrator four hours at $40{ }^{\circ} \mathrm{C}$.

\section{Statistical analysis}

Data statistical analysis was performed with Excel (MS Office) and Quattro programs. ANOVA oneway together with T, F and $\mathrm{Z}$ tests were used. For correlation between two data sets Excel statistical functions with a significance level $\mathrm{p}<0.05$ were used (Pomohaci and Vâșcă - Zamfir, 2017).

\section{Results and Discussion}

\section{Total growth length}

Significant differences were noticed between V1 - V8 variants for all three roses' cultivars (Figure 3).

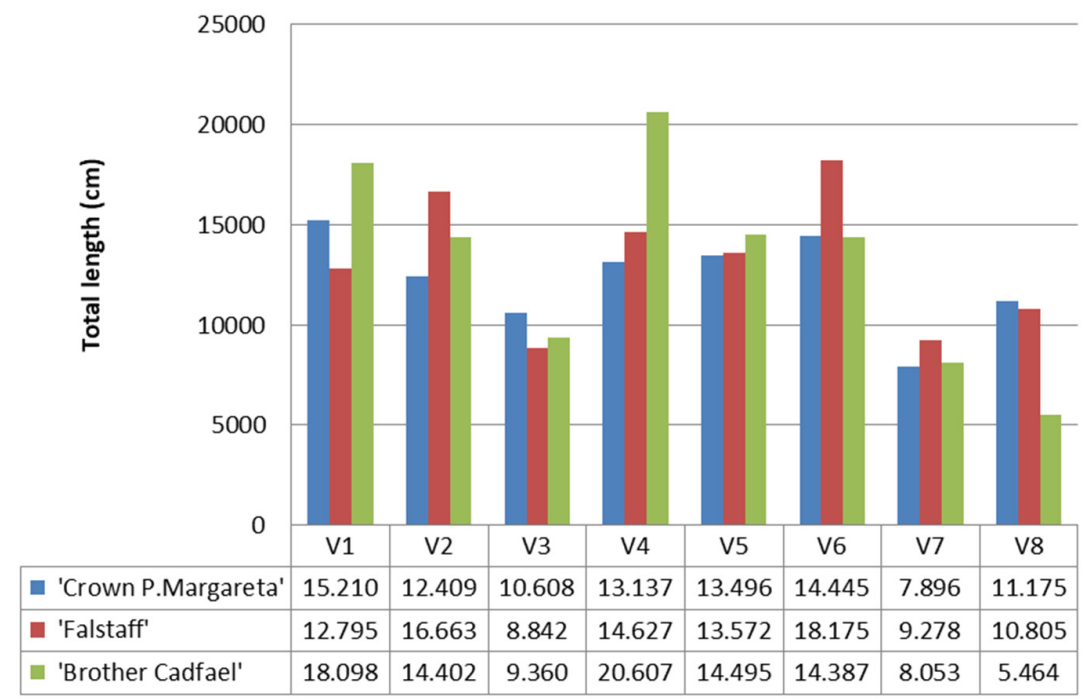

Figure 3. Influence of ameliorative plants on length of total vegetative growth $(\mathrm{cm})$

The highest total vegetative growth was registered in V4 (Sinapis + Tagetes) and V6 (Tagetes + Phacelia) for all three cultivars while V3 (Phacelia) and V7 (Tagetes) for the lowest values. 'Crown Princess Margareta' cultivar had the highest total vegetative growth in V1, V2, V4, V5, V6 and V8 variants while the lowest in V7 and V3 variants. 'Falstaff cultivar had the highest total vegetative growth in V6, V2, V4 and V5 variants while the lowest in V3, V7, V8 and V1 variants. 'Brother Cadfael' cultivar had the highest total vegetative growth in $\mathrm{V} 4, \mathrm{~V} 1$ and V6 variants while the lowest in V8, V3 and V7 variants. Positive significant correlation between total vegetative growth with soil bacteria number respectively with potential phosphorus in $0-20$ horizon were noticed at 'Brother Cadfael' cultivar (Figure 4). The results were similar with Zală (2015), soil microorganism being positive correlated with plant growth.

In 20-40 cm horizon, significant positive correlations between total vegetative growth and soil potential potassium content were registered. At 'Brother Cadfael' cultivar, there were also correlations with soil potential phosphorus and humus content (Figure 5). The results confirmed Hessayon (2005), Madjar and Davidescu (2009). 


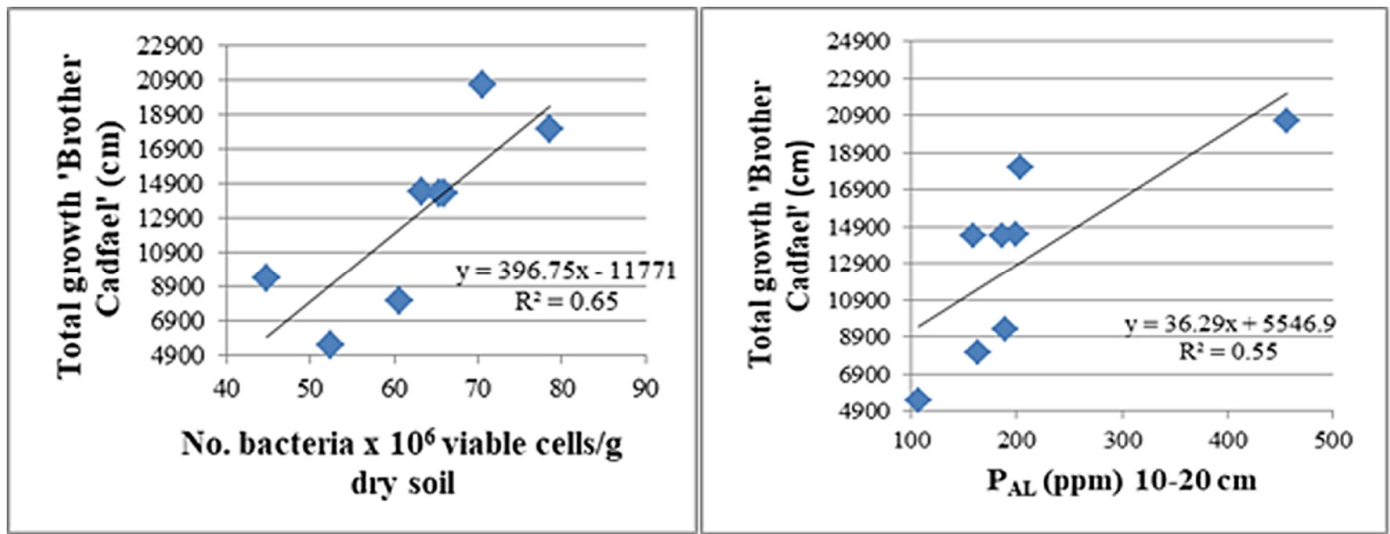

Figure 4. Correlation between total vegetative growth with soil bacteria no. and $\mathrm{P}_{\mathrm{AL}}$
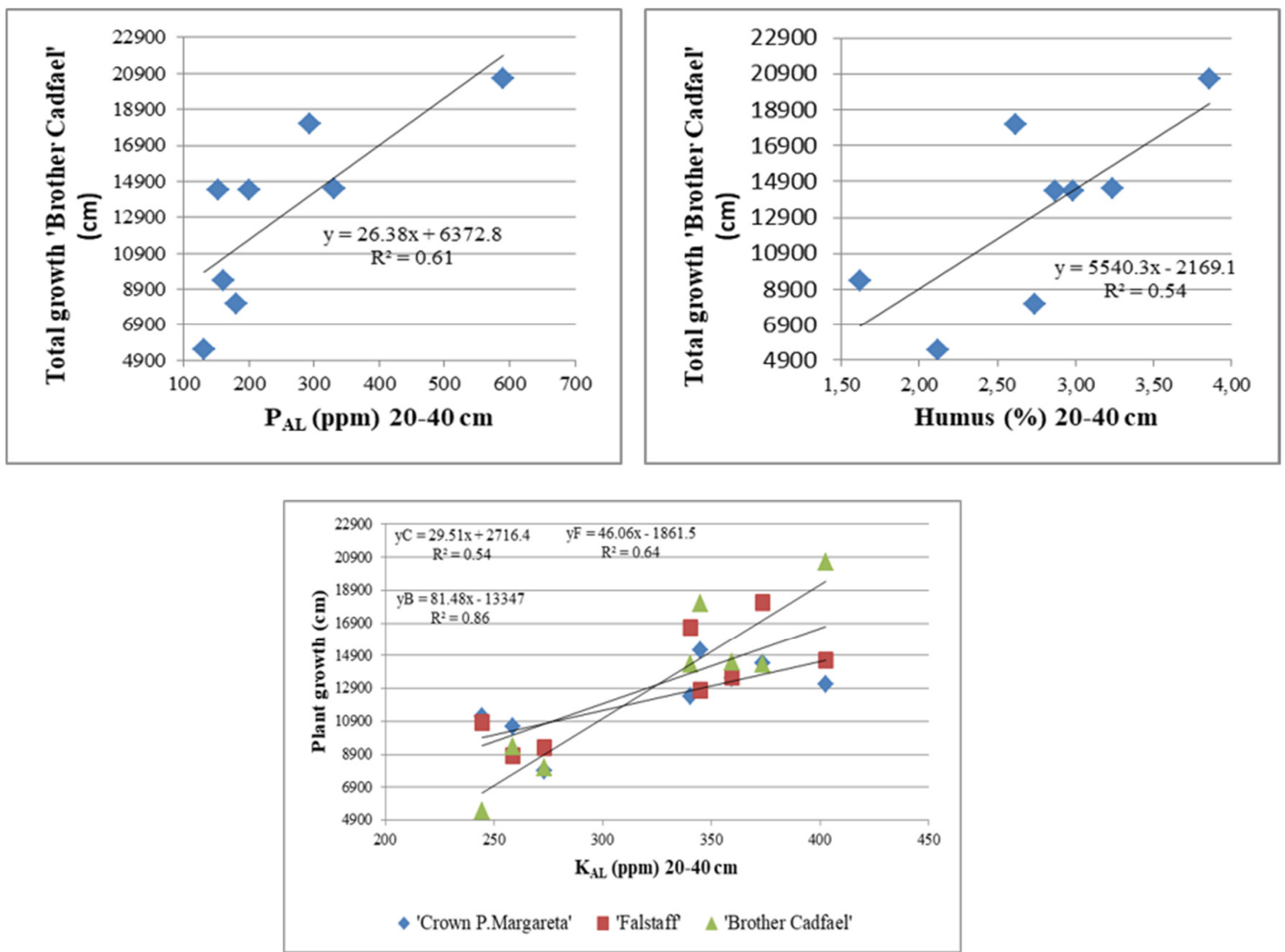

Figure 5. Correlation between total vegetative growth and soil agrochemical parameters in $20-40 \mathrm{~cm}$ horizon

\section{Total rose shoots number}

Shoots number was an important quality parameter for edible roses, being correlated with flowers number, respectively total petal production.

V1 (Sinapis) and V4 (Sinapis + Tagetes) presented the highest values for all three climbing cultivars. V7 and V3 variants presented the lowest shoots number for two cultivars (Figure 6). 'Crown Princess Margareta' cultivar had the highest shoots number in V1, V2, V4-V6 and V8 variants while the lowest in V7 and V3 variants. 'Falstaff cultivar had no significant differences between the eight variants. 'Brother Cadfael' cultivar had the highest shoots number in V4 and V1 variants while the lowest in V8, V7 and V3 variants. Positive significant correlation between total shoots and bacteria number was noticed at 'Brother Cadfael' cultivar $\left(\mathrm{R}^{2}\right.$ 
$=0.65 ; \mathrm{y}=10.1 \mathrm{x}-257.26 ; \mathrm{y}=$ total shoots number and $\mathrm{x}=$ soil bacteria number). Significant positive correlations between total shoots number with mineral nitrogen, phosphorus, potassium and humus content have been observed (Table 1). The results are similar with data presented by Madjar and Davidescu (2009) and Hessayon (2005).

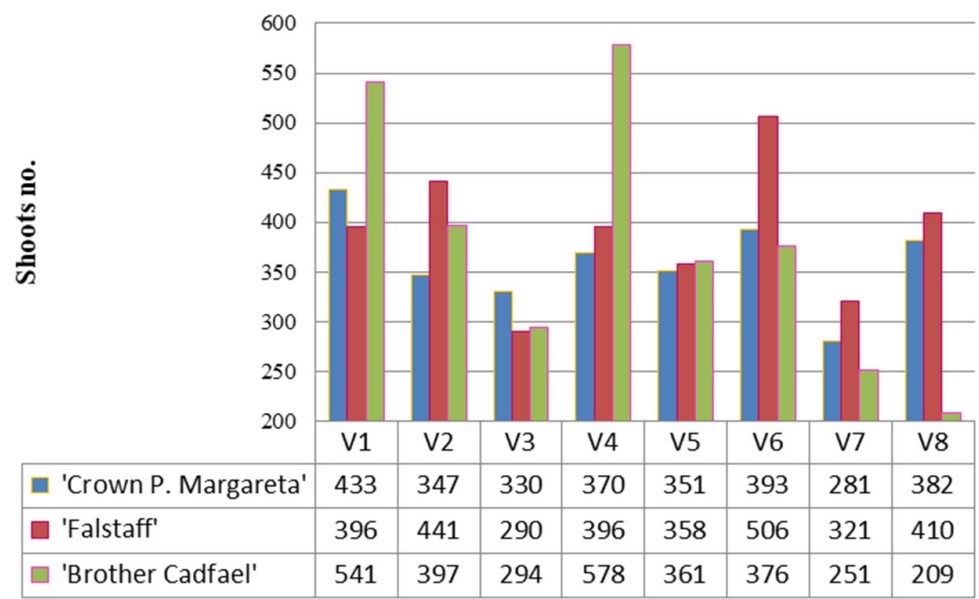

Figure 6. Total shoots number at the three rose cultivars

Table 1. Significant correlation between shoots number and soil agrochemical parameters

\begin{tabular}{|c|c|c|}
\hline Correlated factors & $\mathrm{R}^{2}$ & Regression equation \\
\hline $\begin{array}{c}\mathrm{y}=\text { total shoots number 'Brother Cadfael' } \\
\mathrm{x}=\mathrm{P}_{\mathrm{AL}}(\mathrm{ppm}) 0-20 \mathrm{~cm}\end{array}$ & 0.57 & $\mathrm{y}=0.94 \mathrm{x}+180.33$ \\
\hline $\begin{array}{c}\mathrm{y}=\text { total shoots number 'Falstaff } \\
\mathrm{x}=\mathrm{N} \text { mineral }(\mathrm{ppm}) 20-40 \mathrm{~cm}\end{array}$ & 0.61 & $\mathrm{y}=7.52 \mathrm{x}+338.61$ \\
\hline $\begin{array}{c}\mathrm{y}=\text { total shoots number 'Brother Cadfael' } \\
\mathrm{x}=\mathrm{P}_{\mathrm{AL}}(\mathrm{ppm}) 20-40 \mathrm{~cm}\end{array}$ & 0.61 & $\mathrm{y}=0.67 \mathrm{x}+205.43$ \\
\hline $\begin{array}{c}\mathrm{y}=\text { total shoots number 'Brother Cadfael' } \\
\mathrm{x}=\mathrm{K}_{\mathrm{AL}}(\mathrm{ppm}) 20-40 \mathrm{~cm}\end{array}$ & 0.69 & $\mathrm{y}=1.86 \mathrm{x}-226.83$ \\
\hline $\begin{array}{c}\mathrm{y}=\text { total shoots number 'Brother Cadfael' } \\
\mathrm{x}=\text { humus }(\%) 20-40 \mathrm{~cm}\end{array}$ & 0.42 & $\mathrm{y}=123.54 \mathrm{x}+35.22$ \\
\hline
\end{tabular}

\section{Average shoots length}

At 'Crown Princess Margareta' cultivar, average shoots length was similar in all variants, varying from $29.35 \pm 4.57 \mathrm{~cm}$ (V8) to $37.21 \pm 7.93$ (V5) (Figure 7). At 'Falstaff cultivar, there was a significant difference between variants, between $26.53 \pm 3.13 \mathrm{~cm}$ in V7 (similar with V8 and V3) and $38.89 \pm 8.47 \mathrm{~cm}$ in V2 (similar with V1, V4, V5 and V6).

At 'Brother Cadfael' cultivar, average shoots length varied between $27.39 \pm 7.92 \mathrm{~cm}$ in V8 (similar with V7 and V3) to $39.69 \pm 7.80 \mathrm{~cm}$ in V5 (similar with V6, V2, V4 and V1). For all cultivars, average shoots length was bigger than values mentioned by Hoza (2000) of $15-20 \mathrm{~cm}$, due to average high of plants and climbing type.

In 20-40 soil horizon, significant positive correlation was registered between averages shoots length and soil potential potassium assimilable content (Figure 8 ). At 'Falstaff cultivar, positive correlation with humus content was noticed $\left(R^{2}=0.49 ; y=4.99 x+19.94 ; y=\right.$ average shoots length and $x=$ humus $\left.(\%) 20-40 \mathrm{~cm}\right)$. 


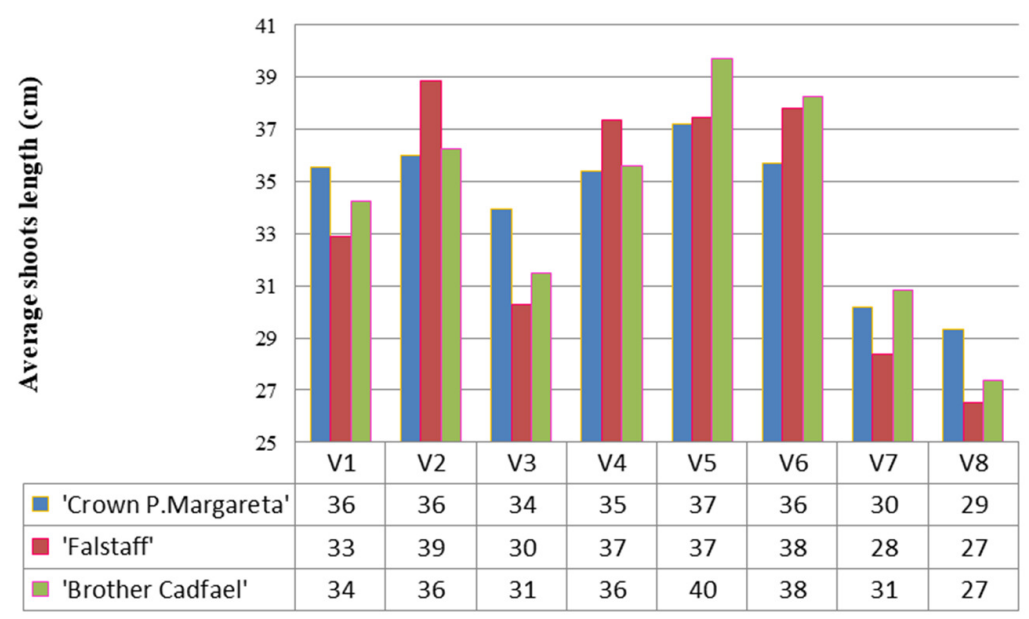

Figure 7. Average shoots length for three climbing edibles rose cultivars

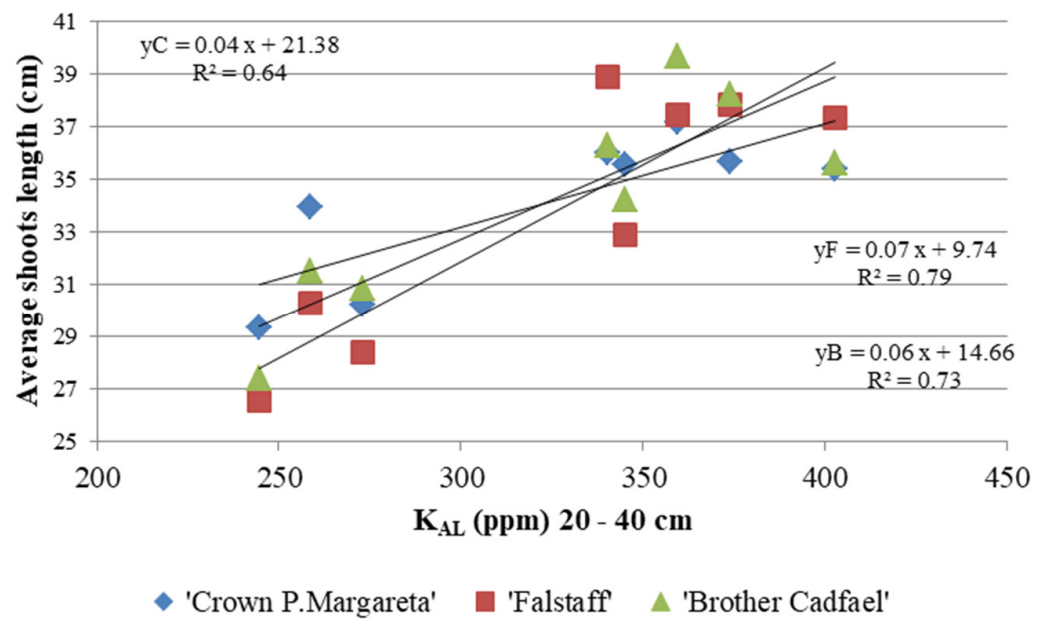

Figure 8. Correlation between averages shoots length $(\mathrm{cm})$ and soil agrochemical parameters

\section{Flowers number in the first flowering stage}

The influence of experimental variants on flowers production in the first stage of 2017 year (Table 2) showed that at 'Crown Princess Margareta' cultivar, the biggest flowers number were in V3.2 variant $(1,272)$ and the lowest in V8.3 variant (175). Both mulched rows had a significant flowers number highest than control row, without mulch. At the wood chips mulched and at the un-mulched rows there were no significant differences between ameliorative plants variants. At the wool-mulched rows, there were noticed a significant difference between V7.2 variant with 82 flowers and all the other.

At 'Falstaff cultivar, the biggest flowers number were in V5.1 variant (148) and the lowest in V5.2 variant (42). There were no significant differences between the mulched and un-mulched rows. There were significant differences on the mulched rows between ameliorative plants variants, varying between V8.1, V7.1, V3.1 to V5.1, V6.1 (wood chips mulched rows) respectively between V5.2, V8.2 to V2.2, V4.2, V6.2 (wool mulched rows). Comparing the ameliorative plants variants, the lowest flowers number were in $\mathrm{V} 7$ and $\mathrm{V} 8$ variants and the highest in V6, V2, V1, V5 and V4 variants. At 'Brother Cadfael' cultivar, the highest flowers number was in V1.2 variant (617) and the lowest in V7.3 variant (70). There were no significant differences between the mulched and un-mulched rows. There were significant differences on the rows, the flowers number varying between V7.1 (97) to V4.1 (524) and V5.1 (454) at wood chips rows; V8.2 (213) to V1.2 (617) and V2.2 (510) at wool mulched rows; V7.3 (70) to V1.3 (541), V5.3 (502), V2.3 (498) at un-mulched rows. 
Comparing variants, the lowest flowers number was in V7 and V8 variants and the highest in V1, V5, V2 and V4. At 'Crown Princess Margareta' cultivar, on the un-mulched rows, there was a positive correlation between flowers number and soil respiration coefficient $\left(\mathrm{R}^{2}=0.50 ; \mathrm{y}=28.27 \mathrm{x}-1805.5\right)$ and at 'Falstaff cultivar, a negative one on the wood chips mulched rows $\left(R^{2}=0.43 ; y=-8.22 x+1010.2\right)$.

Table 2. Number of flowers at three rose varieties on eight variants

\begin{tabular}{|c|c|c|c|c|c|c|c|c|c|}
\hline \multirow{2}{*}{ Variant } & \multicolumn{3}{|c|}{ 'Crown P. Margareta' } & \multicolumn{3}{c|}{ 'Falstaff } & \multicolumn{3}{c|}{ 'Brother Cadfael' } \\
\cline { 2 - 11 } & Vn.1 & Vn.2 & Vn.3 & Vn.1 & Vn.2 & Vn.3 & Vn.1 & Vn.2 & Vn.3 \\
\hline V1 & 1,140 & 1,163 & 837 & 390 & 380 & 298 & 369 & 617 & 541 \\
\hline V2 & 1,231 & 1,132 & 913 & 346 & 501 & 358 & 267 & 510 & 498 \\
\hline V3 & 857 & 1,272 & 603 & 220 & 301 & 315 & 185 & 353 & 241 \\
\hline V4 & 1,130 & 1,022 & 968 & 324 & 486 & 260 & 524 & 314 & 380 \\
\hline V5 & 1,181 & 856 & 1,069 & 593 & 125 & 281 & 454 & 324 & 502 \\
\hline V6 & 1,066 & 1,059 & 688 & 489 & 463 & 332 & 239 & 355 & 309 \\
\hline V7 & 891 & 328 & 665 & 192 & 236 & 156 & 97 & 263 & 70 \\
\hline V8 & 954 & 1,493 & 175 & 191 & 159 & 245 & 227 & 213 & 153 \\
\hline Total & 8,450 & 8,325 & 5,918 & 2,745 & 2,651 & 2,245 & 2,362 & 2,949 & 2,694 \\
\hline Total & \multicolumn{3}{|c|}{22,693} & 7,641 & & & 8,005 & \\
\hline
\end{tabular}

Table 3. Correlation between total number of flowers and soil agrochemical parameters

\begin{tabular}{|c|c|c|}
\hline Correlated factors & $\mathrm{R}^{2}$ & Regression equation \\
\hline $\begin{array}{c}\mathrm{y}=\text { total flower number 'Brother Cadfael' } \\
x=\mathrm{pH} \text { Vn.1 }\end{array}$ & 0.72 & $y=-566.39 x+4515.5$ \\
\hline $\begin{array}{c}\mathrm{y}=\text { total flower number }{ }^{\circ} \text { Falstaff } \\
\mathrm{x}=\text { total soluble salts }(\%) \text { Vn.2 }\end{array}$ & 0.47 & $y=7484.5 x-201.89$ \\
\hline $\begin{array}{c}\mathrm{y}=\text { total flower number }{ }^{\prime} F \text { Falstaff } \\
x=\mathrm{N} \text { mineral } \mathrm{Vn} .2\end{array}$ & 0.46 & $y=9.10 x-33.88$ \\
\hline $\begin{array}{l}\mathrm{y}=\text { total flower number 'Crown Princess Margareta' } \\
\qquad \mathrm{x}=\mathrm{P}_{\mathrm{AL}}(\mathrm{ppm})\end{array}$ & 0.46 & $y=1.8 x+649.81$ \\
\hline $\begin{array}{l}\mathrm{y}=\text { total flower number 'Brother Cadfael' } \\
\qquad \mathrm{x}=\mathrm{P}_{\mathrm{AL}}(\mathrm{ppm})\end{array}$ & 0.45 & $y=1.82 x-116.73$ \\
\hline $\begin{array}{l}y=\text { total flower number 'Crown Princess Margareta' } \\
\qquad x=K_{A L}(p p m) \text { Vn.1 }\end{array}$ & 0.83 & $y=2.04 x+308.88$ \\
\hline $\begin{array}{c}\mathrm{y}=\text { total flower number 'Falstaff } \\
\mathrm{x}=\mathrm{K}_{\mathrm{AL}}(\mathrm{ppm}) \text { Vn.1 }\end{array}$ & 0.52 & $y=1.68 x-272.61$ \\
\hline $\begin{array}{l}y=\text { total flower number 'Brother Cadfael' } \\
\qquad x=K_{A L}(p p m) \text { Vn.1 }\end{array}$ & 0.43 & $y=1.51 x-257.67$ \\
\hline $\begin{array}{c}y=\text { total flower number 'Falstaff } \\
x=K_{A L}(p p m) \text { Vn.2 }\end{array}$ & 0.89 & $y=0.98 x-211.96$ \\
\hline $\begin{array}{l}\mathrm{y}=\text { total flower number 'Brother Cadfael' } \\
\qquad \mathrm{x}=\mathrm{K}_{\mathrm{AL}}(\mathrm{ppm}) \mathrm{Vn} .2\end{array}$ & 0.53 & $y=0.85 x-173.46$ \\
\hline $\begin{array}{c}\mathrm{y}=\text { total flower number 'Crown Princess Margareta' } \\
x=\text { humus (\%) Vn.1 }\end{array}$ & 0.54 & $y=383.71 x-14.29$ \\
\hline $\begin{array}{c}y=\text { total flower number 'Crown Princess Margareta' } \\
x=\text { humus (\%) Vn.3 }\end{array}$ & 0.47 & $y=587.92 x-854.25$ \\
\hline $\begin{array}{c}\mathrm{y}=\text { total flower number 'Brother Cadfael' } \\
\mathrm{x}=\text { humus (\%) Vn.2 }\end{array}$ & 0.61 & $y=323.94 x-525.05$ \\
\hline
\end{tabular}


At 'Crown Princess Margareta' cultivar, there were significant positive correlations between flowers number and soil phosphorus content at wood chips mulched rows, with soil potassium and humus content at wood chips mulched and un-mulched rows. At 'Falstaff cultivar, there were significant positive correlations between flowers number with total soluble salts and mineral nitrogen at wool-mulched rows and with soil potassium content at the two mulched rows. At 'Brother Cadfael' cultivar, there were negative significant correlation with soil $\mathrm{pH}$ at wood chips mulched rows and positive correlations with soil phosphorus content at wood chips variants, with soil potassium at the two mulched rows and with humus at wool mulched rows (Table 3).

Positive correlations with soil total soluble salts content, mineral nitrogen, phosphorus, potassium, humus confirm the importance of these elements in flower production (Madjar and Davidescu, 2009; Hessayon, 2009). 'Brother Cadfael' cultivar showed a negative correlation with soil $\mathrm{pH}$ in wood chips mulched variants, confirming the tolerance to soil reaction, with preference to low acid to neutral soils with $\mathrm{pH}$ between 5.5 and 7.2 (Milică et al., 2010). Average $\mathrm{pH}$ for wood chips rows was $7.45 \pm 0.21$.

\section{Flowers number in the second flowering stage}

All the three climbing roses had repeteated flowering. The number of flowers from the second stage was presented in Table 4 .

Table 4. Flowers number in the second flowering stage

\begin{tabular}{|c|c|c|c|c|c|c|c|c|c|}
\hline \multirow{2}{*}{ Variant } & \multicolumn{3}{|c|}{ 'Crown P. Margareta' } & \multicolumn{3}{c|}{ 'Falstaff } & \multicolumn{3}{c|}{ 'Brother Cadfael' } \\
\cline { 2 - 12 } & Vn1 & Vn2 & Vn3 & Vn1 & Vn2 & Vn3 & Vn1 & Vn2 & Vn3 \\
\hline V1 & 489 & 1,025 & 588 & 520 & 816 & 479 & 289 & 848 & 595 \\
\hline V2 & 678 & 1,173 & 487 & 450 & 1,037 & 319 & 191 & 637 & 457 \\
\hline V3 & 271 & 1,039 & 280 & 150 & 571 & 388 & 116 & 464 & 259 \\
\hline V4 & 942 & 992 & 891 & 750 & 1,229 & 826 & 782 & 680 & 1,000 \\
\hline V5 & 920 & 672 & 906 & 809 & 381 & 616 & 496 & 459 & 512 \\
\hline V6 & 990 & 685 & 635 & 630 & 786 & 791 & 337 & 768 & 344 \\
\hline V7 & 601 & 284 & 395 & 171 & 655 & 510 & 171 & 568 & 138 \\
\hline V8 & 318 & 1,132 & 49 & 181 & 227 & 305 & 86 & 252 & 228 \\
\hline Total & 5,209 & 7,002 & 4,231 & 3,661 & 5,702 & 4,234 & 2,468 & 4,676 & 3,533 \\
\hline Total & \multicolumn{9}{|c|}{16,442} \\
\hline
\end{tabular}

At 'Crown Princess Margareta' cultivar, the highest flowers number was in V2.2 $(1,173)$ and the lowest in V8.3 (49). There were no significant differences between mulch rows flowers number. On the wood chips rows, the flowers number varied from V3.1 (271) and V8.1 (318) to V6.1 (990), V4.1 (942) and V5.1 (920). At the wool-mulched rows, the flowers number varied from V7.2 (284) to V2.2 (1,173) and V8.2 (1,132). On the un-mulched rows, V8.3 (49) and V7.3 (395) had the lowest flowers number and V5.3 (906) respectively V4.3 (891) the biggest. Comparing V1-V8 variants, the lowest flowers number for 'Crown Princess Margareta' cultivar was in V7 and V8 and the highest in V4, V5 and V2. At 'Falstaff cultivar, the highest flower number was in V4.2 (1,229) and the lowest in V3.1 (150). There were no significant differences between mulch rows flower numbers. On the wood chips mulched rows, the flowers numbers varied from V3.1 (150), V7.1 (171) and V8.1 (181) to V5.1 (809) and V4.1 (750). At the wool-mulched rows, the flowers number varied from V8.2 (227) and V5.2 (381) to V4.2 (1.229) and V2.2 (1.037). On the un-mulched rows, V8.3 (305) and V2.3 (319) had the lowest flowers number and V4.3 (826) respectively V6.3 (791) the highest. Comparing V1-V8 variants, the lowest flowers number for 'Falstaff cultivar was in V8 and the highest in V4 and V6. At 'Brother Cadfael' cultivar, the highest flowers number was in V4.3 (1,000) and the lowest in V8.1 (86). There were significant differences between mulch rows flower numbers. On the wood chips mulched rows, the flowers 
number varied from V8.1 (86) and V3.1 (116) to V4.1 (782) and V5.1 (496). At the wool-mulched rows, the flowers number varied from V8.2 (252) to V1.2 (848) and V6.2 (768). On the un-mulched rows, V7.3 (138) and V8.3 (228) had the lowest flowers number and V4.3 $(1,000)$ the highest. Comparing V1-V8 variants, the lowest flowers number for 'Brother Cadfael' cultivar was in V8 and the highest in V4 and V1. For all three cultivars were observed more correlations that are significant.

For all three cultivars, on the wood-chips mulched and un-mulched rows, there were negative correlation between flowers number and soil $\mathrm{pH}$. At 'Falstaff cultivar positive correlations with soil total soluble salts and with soil $\mathrm{P}_{\mathrm{Al}}$ content on the wool - mulched rows were noticed. At 'Brother Cadfaell' cultivar positive correlations with soil $\mathrm{P}_{\mathrm{Al}}$ content on the wool-mulched and un-mulched rows were registered (Table 5).

Table 5. Correlations between total number of flowers and soil parameters in second flowering stage

\begin{tabular}{|c|c|c|}
\hline Correlated factors & $\mathrm{R}^{2}$ & Regression equation \\
\hline $\mathrm{y}=$ total flower number 'Crown Princess Margareta' $\mathrm{x}=\mathrm{pH}-\mathrm{Vn} .1$ & 0.57 & $y=-991.76 x+8041$ \\
\hline $\begin{array}{l}y=\text { total flower number 'Falstaff } \\
x=\mathrm{pH}-\text { Vn.1 }\end{array}$ & 0.72 & $y=-1055.4 x+8321.7$ \\
\hline $\begin{array}{l}\mathrm{y}=\text { total flower number 'Brother Cadfael' } \\
\qquad \mathrm{x}=\mathrm{pH}-\mathrm{Vn} .1\end{array}$ & 0.89 & $y=-1021.6 x+7921$ \\
\hline$y=$ total flower number 'Crown Princess Margareta' $x=p H-V n .3$ & 0.59 & $y=-1049.2 x+8366.3$ \\
\hline $\begin{array}{l}y=\text { total flower number 'Falstaff } \\
x=\mathrm{pH}-\text { Vn.3 }\end{array}$ & 0.57 & $y=-704.93 x+5795.1$ \\
\hline $\begin{array}{l}y=\text { total flower number 'Brother Cadfael' } \\
\qquad x=p H-V n .3\end{array}$ & 0.58 & $y=-969.19 x+7681.5$ \\
\hline $\begin{array}{l}\mathrm{y}=\text { total flower number 'Falstaff } \\
\mathrm{x}=\text { total soluble salts }(\%)-\mathrm{Vn} .2\end{array}$ & 0.69 & $y=20095 x-719.03$ \\
\hline $\begin{array}{l}\mathrm{y}=\text { total flower number 'Brother Cadfael' } \\
\qquad \mathrm{x}=\mathrm{N} \text { mineral }(\mathrm{ppm}) \text { Vn.2 }\end{array}$ & 0.66 & $y=14.07 x+19.60$ \\
\hline $\begin{array}{l}y=\text { total flower number 'Brother Cadfael' } \\
\qquad x=P_{A L}(p p m) \text { Vn.1 }\end{array}$ & 0.56 & $y=3.31 x-439.45$ \\
\hline $\begin{array}{l}\mathrm{y}=\text { total flower number 'Brother Cadfael' } \\
\qquad \mathrm{x}=\mathrm{P}_{\mathrm{AL}}(\mathrm{ppm}) \text { Vn.3 }\end{array}$ & 0.72 & $y=3.55 x-477.37$ \\
\hline $\begin{array}{l}\mathrm{y}=\text { total flower number 'Falstaff } \\
\qquad \mathrm{x}=\mathrm{P}_{\mathrm{AL}}(\mathrm{ppm}) \text { Vn.2 }\end{array}$ & 0.70 & $y=6.26 x-839.24$ \\
\hline $\begin{array}{l}\mathrm{y}=\text { total flower number 'Brother Cadfael' } \\
\qquad \mathrm{x}=\mathrm{P}_{\mathrm{AL}}(\mathrm{ppm}) \text { Vn.2 }\end{array}$ & 0.52 & $y=3.14 x-193.66$ \\
\hline $\begin{array}{l}y=\text { total flower number 'Crown Princess Margareta' } \\
\qquad x=K_{A L}(p p m) \text { Vn.1 }\end{array}$ & 0.63 & $y=3.59 x-663.78$ \\
\hline $\begin{array}{l}\mathrm{y}=\text { total flower number }{ }^{'} \text { Falstaff } \\
x=K_{\mathrm{AL}}(\mathrm{ppm}) \text { Vn.1 }\end{array}$ & 0.74 & $y=3.66 x-885.07$ \\
\hline $\begin{array}{l}\mathrm{y}=\text { total flower number 'Brother Cadfael' } \\
\qquad \mathrm{x}=\mathrm{K}_{\mathrm{AL}}(\mathrm{ppm}) \text { Vn.1 }\end{array}$ & 0.44 & $y=2.48 x-599.82$ \\
\hline $\begin{array}{l}\mathrm{y}=\text { total flower number 'Falstaff } \\
\mathrm{x}=\mathrm{K}_{\mathrm{AL}}(\mathrm{ppm}) \text { Vn.2 }\end{array}$ & 0.47 & $y=1.77 x-339.09$ \\
\hline $\begin{array}{l}\mathrm{y}=\text { total flower number 'Brother Cadfael' } \\
\qquad \mathrm{x}=\mathrm{K}_{\mathrm{AL}}(\mathrm{ppm}) \text { Vn.2 }\end{array}$ & 0.80 & $y=1.34 x-212$ \\
\hline $\begin{array}{c}\mathrm{y}=\text { total flower number 'Crown Princess Margareta' } \\
\mathrm{x}=\text { humus (\%) Vn.1 }\end{array}$ & 0.47 & $y=718.29 x-1352.9$ \\
\hline $\begin{array}{l}\mathrm{y}=\text { total flower number 'Brother Cadfael' } \\
\mathrm{x}=\text { humus }(\%) \text { Vn.1 }\end{array}$ & 0.50 & $y=701.2 x-1498.7$ \\
\hline
\end{tabular}

Other positive correlations were with soil $\mathrm{K}_{\mathrm{Al}}$, humus content on the wood chips or woold mulched rows. Positive correlations between flowers number and soil total soluble salts, $\mathrm{P}_{\mathrm{Al}}, \mathrm{K}_{\mathrm{Al}}$, humus content 
confirmed their importance in flower production, similar with Hessayon (2005), Madjar and Davidescu (2009). In the second flowering stage, all three cultivars presented negative correlation with soil $\mathrm{pH}$ on the wood chips mulched and un-mulched rows, with averages values of $7.45 \pm 0.21$ respectively $7.47 \pm 0.21$, higher than the optimum ones for roses (pH between 5.5 and 7.2 (Milică et al., 2010).

\section{Comparation between the two flowering stages}

There were significant differences between total flowers number for 'Crown Princess Margareta' cultivar, where in the second stage had fewer flowers that in the first (16,442 comparing with 22,580) and 'Falstaff cultivar where in the second stage had more flowers (13,597 comparing with 7,511). For 'Crown Princess Margareta' cultivar, there was also a significant difference on the wood chips mulched rows, in the second stage being fewer flowers. On the wool mulched and un-mulched rows, the average total flowers number was similar between the two stages. At 'Falstaff cultivar, total flowers number on the wood and un-mulched rows were significant higher in second stage (Vn.2: 5,702 comparing with 2,651; Vn.3: 4,234 comparing with $2,115)$. At 'Brother Cadfael' cultivar, total flowers number on the wool-mulched rows was significant higher in the second stage (4,676 comparing with 2,949).

\section{Production estimation for edible organic rose orchard}

Average flower, fresh and dehydrated petals weights were presented in Table 6.

Table 6. Flowers and petals weight at three climbing edibles rose cultivars

\begin{tabular}{|c|c|c|c|c|}
\hline Cultivar & $\begin{array}{c}\text { Average flower } \\
\text { weight }(\mathrm{g})\end{array}$ & $\begin{array}{c}\text { Average fresh petals } \\
\text { weight }(\mathrm{g})\end{array}$ & (\%) & $\begin{array}{c}\text { Average dehydrated } \\
\text { petals weight }(\mathrm{g})\end{array}$ \\
\hline 'Crown P. Margareta' & $7.04 \pm 1.04$ & $6.17 \pm 0.99$ & $88 \%$ & 1.09 \\
\hline 'Falstaff & $10.39 \pm 2.00$ & $9.11 \pm 1.75$ & $88 \%$ & 1.66 \\
\hline 'Brother Cadfael' & $8.85 \pm 2.24$ & $7.51 \pm 2.06$ & $85 \%$ & 1.45 \\
\hline
\end{tabular}

The estimated flower and petal production for one-hectare edible rose orchards was presented in Table 7 , considering 3,750 plants per hectare.

Table 7. Estimated flowers and petals production for 1 ha rose plantation

\begin{tabular}{|c|c|c|c|}
\hline \multirow{2}{*}{ Cultivar } & \multicolumn{3}{|c|}{ Two flowering stages * } \\
\cline { 2 - 4 } & Flowers $(\mathrm{t})$ & Fresh petals $(\mathrm{t})$ & Dehydrated petals $(\mathrm{t})$ \\
\hline 'Crown P. Margareta' & 10.73 & 9.44 & 1.66 \\
\hline 'Falstaff & 8.56 & 7.54 & 1.37 \\
\hline 'Brother Cadfael' & 6.39 & 5.62 & 1.05 \\
\hline
\end{tabular}

Estimated production was highest than other cultivars like Rosa damascena Mill., where the average was between 2.6-5.26 $\mathrm{t} \mathrm{ha}^{-1}$ (Chira, 2009; Samadiyan-Sarbangholi et al., 2013).

\section{Conclusions}

Climbing edible roses ('Crown Princess Margareta', 'Falstaff and 'Brother Cadfael') cultivated with an organic technology had flowers production higher than the usual edible roses used in the actual plantations. Taking into account data obtained in the two flowering stages in 2017, the average yield per hectare cultivated with 'Crown Princess Margareta' was $9.44 \mathrm{t}$ petals ha ${ }^{-1}$, for 'Falstaff cultivar $7.54 \mathrm{t}$ petals ha ${ }^{-1}$ and for 'Brother Cadfael' $5.62 \mathrm{t} \mathrm{ha}^{-1}$. The influences of ameliorative plants (Sinapis alba L., Phacelia tanacetifolia L., Tagetes 
patula L.) and of organic mulch (wood chips, wool) were noticed through several significant correlations bertween total vegetative growth and flowers numbers and soil microbiological and agrochemical parameters.

\section{Acknowledgements}

This research received no specific grant from any funding agency in the public, commercial, or not-forprofit sectors.

\section{Conflict of Interests}

The authors declare that there are no conflicts of interest related to this article.

\section{References}

Austin D (2012). Handbook of Roses - European edition. David Austin Press, UK.

Beales P, Cairns T, Duncan W, Fagan G, Grant W, Grapes K, ... Ruston D (1998). Botanica's roses. The Encyclopaedia of Roses. Grange Books PLC, Kent, UK.

Bojor O, Răducanu D (2007). Plante și miresme biblice: hrană pentru suflet și trup [Biblical plants and fragrances: food for the soul and body]. Fiat Lux Publishing House, Bucharest.

Butcaru AC, Stănică F, Matei GM, Matei S (2019). Influences of soil ameliorative plant species on the organic edible rose culture. Acta Horticulturae 1242:107-114.

Butcaru AC, Stănică F (2018). Cultivation technology of organic roses for petal production. Scientific Papers, Series B, Horticulture, LXII:203-210.

Butcaru AC, Stănică F, Madjar R (2017a). Influence of ameliorative plants and mulch on some soil agrochemical characteristics in an organic edible rose crop. Scientific Papers, Series B, Horticulture LXI:101-106.

Butcaru AC, Stănică F, Matei GM, Matei S (2017b). Soil microbial activity in an organic edible rose crop. Scientific Papers, Series B, Horticulture LXI:107-112.

Chira L (2009). Cultura arbuștilor fructiferi [Fruit bushes culture]. M.A.S.T. Publishing House, Bucharest.

Dong X, Jiang X, Kuang G, Wang Q, Zhong M, Jin D, Hu J (2017). Genetic control of flowering time in woody plants: Roses as an emerging model. Plant Diversity 39:104-110.

Fernandes L, Casal S, Pereira JA, Saraiv JA, Ramalhosa E (2017). Edible flowers: A review of the nutritional, antioxidant, antimicrobial properties and effects on human health. Journal of Food Composition and Analysis 60:38-50.

Friedman H, Agami O, Vinokur Y, Droby S, Cohen L, Refaeli G, Resnick N, Umiel N (2010). Characterization of yield, sensitivity to Botrytis cinerea and antioxidant content of several rose species suitable for edible flowers. Scientia Horticulturae 123(3):395-401.

Hessayon DG (2005). Expert în cultivarea trandafirilor [Expert in rose cultivation]. BIC ALL Publishing House, Bucharest.

Hoza D (2000). Pomologie [Pomology]. Prahova Publishing House, Ploiești.

Lambraki M (2001). Plantes, herbees, legumes verts, fruits [Plants, Herbs, Green Vegetables, Fruits]. Lambraki Publishing House, Greece.

Lia A, Lia S, Lia HB, Xua DP, Xub XR, Chenc F (2014). Total phenolic contents and antioxidant capacities of 51 edible and wild flowers. Journal of Functional Foods 6:319-330.

Madjar R, Davidescu V (2009). Agrochimie [Agrochemistry]. Ex Terra Aurum Publishing House, Bucharest.

Matei GM, Dumitru S, Matei S, Butcaru A, Stănică F (2017). Microbiological aspects in soil microbiome composition and activity under the influence of organic mulches. International Multidisciplinary Scientific GeoConference: SGEM: Surveying Geology and Mining Ecology Management 17:813-820.

McKinley M (2008). Complete guide to roses. The Scotts Miracle - Gro Company, USA. 
Milică C, Bavaru A, Bavaru E (2010). Trandafirul: gingășie, frumusețe, sănătate. Monografia genului Rosa [Rose: delicacy, beauty, health. Monography Rose genus]. Pim Publishing House, Iași.

Pomohaci C, Vâșcă-Zamfir D (2017). Elemente de biostatistică informatică aplicate în floricultură [Elements of computer biostatistics applied in floriculture]. Ex Terra Aurum Publishing House, Bucharest.

Samadiyan-Sarbangholi V, Abbaszadeh B, Lebaschy MH, Tabaei-Aghdaei SR (2013). Investigation the effect of iron chelate and NPK on yield of Rosa damascena for the first time in Iran. International Journal of Forest, Soil and Erosion 3(3):100-103.

Stănică F, Braniște N (2011). Ghid pentru pomicultori [Fruit growers guide]. Ceres Publishing House, Bucharest.

Sumedrea D, Isac I, Iancu M, Olteanu A, Coman M, Duțu I (2014). Pomi, arbuști fructiferi, căpșun. Ghid tehnic și economic [Fruit trees, shrubs, strawberries. Technical and economical guide]. Invel Multimedia Publishing House, Pitești.

Vinokur Y, Rodov V, Reznick N, Rot I, Goldman G, Horev B, Umiel N, Friedman H (2006). Rose petal tea as an antioxidant-rich beverage: cultivar variability. Journal Food Science 71:S42-S47.

Vasilca-Mozăceni A (2002). Incursiune in Fitoterapie [Incursion in Phytotherapy]. Polirom Publishing House, Iași.

Zală CR (2015). Microbiologie agricolă [Agricultural microbiology]. Didactic and Pedagogical Publishing House, Bucharest.

Wagner Ș (2010). Trandafiri cu parfum [Roses with fragrance]. Napoca Star Publishing House, Cluj-Napoca.

OPEN ACCESS

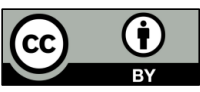

The journal offers free, immediate, and unrestricted access to peer-reviewed research and scholarly work. Users are allowed to read, download, copy, distribute, print, search, or link to the full texts of the articles, or use them for any other lawful purpose, without asking prior permission from the publisher or the author.

License - Articles published in Notulae Botanicae Horti Agrobotanici Cluj-Napoca are Open-Access, distributed under the terms and conditions of the Creative Commons Attribution (CC BY 4.0) License.

(c) Articles by the authors; UASVM, Cluj-Napoca, Romania. The journal allows the author(s) to hold the copyright/to retain publishing rights without restriction. 